\title{
Radiation Copolymerization of Styrene/Acrylic Acid Grafted to Silica Surface For separation and purification purposes: I. Characterization and sorption of some organic compounds and Metals.
}

\author{
H. M. H. Gad ${ }^{1} * \&$ Nabila. A. Maziad ${ }^{2}$ \\ E-mail: drhamdigad@yahoo.com. \\ ${ }^{1}$ Hot Laboratories and Waste Management center \& ${ }^{2}$ National Center for Radiation Research \\ and Technology; Egyptian Atomic Energy Authority.
}

\begin{abstract}
Highly porous and interconnected styrene/acrylic-based porous materials were prepared by radiation-induced graft copolymerization of styrene/acrylic acid monomers onto surface of silica prepared from rice husk ash. The influence of synthesis conditions; such as irradiation dose, monomer concentrations and different solvents; were studied. It was found that the nature of the solvent had profound influence on the copolymerization reaction and water /ethanol mixture was selected as a suitable solvent for copolymerization processes. Graft copolymers of styrene/ acrylic onto silica surface was verified through Fourier Transform Infrared (FTIR) spectroscopy and Eenergy Dispersive Spectroscopy (EDX) was used to investigate the surface profile of representative copolymers by viewing the distribution of elemental nitrogen. Thermo Gravimetric Analysis (TGA) and differential Thermal Analysis (DTA) of the copolymers were investigated. From the characterization of the prepared copolymer it was found that: copolymers of (styrene/acrylic)/silica are considerably different from each other, (styrene/acrylic)/silica based copolymers exhibited relatively more homogenous surface compared to (styrene/acrylic) copolymers. Water uptake percent increases as silica ratio increases to reach 24174 (mol/gm) and this prepared copolymer has a considerable capacity for adsorption of organic compounds and metals.
\end{abstract}

Key words: Irradiation, Graft copolymers, Silica, Rice Husk Ash, Adsorption, Metals.

\section{INTRODUCTION}

One of the commonly used methods for modifying the surface and bulk properties of inorganic materials is to graft monomers onto them by using an irradiation technique known as radiation-induced grafting. Radiation-induced grafting method has the advantages such as simplicity, low cost, control over process and adjustment of the materials composition and structure. In addition, this method assures the grafting of monomers that are difficult to 
polymerize by conventional methods without residues of initiators and catalyst [1]. Radiationinduced grafting method is simply based on the irradiation of a base polymer either in the presence of a monomer (simultaneous radiation grafting) or without a monomer (preirradiation grafting) to create active sites.

It is known that the use of solvents in radiation grafting enhances the accessibility of monomer to the grafting sites due to the ability of the solvent to swell the base polymer and the nature of the solvent may influence the grafting kinetics, the length of grafted chains, and polymer microstructure. Selection of solvents is one of the essential factors toward the success of radiation-induced grafting process. There are only a few publications on the influence of solvents on radiation induced grafting of different monomer/silica combinations [12, 20-23]. However, research is still needed for understanding of the effect of solvents on grafting and properties of copolymers. Consequently, not only the base polymer used but also grafting process (simultaneous radiation grafting, different doses, grafting in aqueous media or bulk grafting, etc. were performed mostly in literature) are very different from our current process and the resultant novel graft copolymers will exhibit quite different properties. Therefore, it is desirable to investigate both the grafting of these monomers onto silica surface and characterization of the resultant graft copolymers in detail.

This study concerns mainly the synthesis of graft copolymers using radiation induced grafting. Grafting conditions especially the effect of solvents during radiation grafting were investigated in detail. Moreover, resultant graft copolymers were characterized by different techniques and tested for adsorption some metals present in aqueous solutions.

\section{EXPERIMENTAL}

\subsection{Materials}

\subsubsection{The base silica: Preparation of silica from rice husk ash.}

Rice husk ash (RHA), was prepared by carbonization of Rice Husk (RH) at $500^{\circ} \mathrm{C}$ for $1 \mathrm{hr}$. RHA was stirred with a solution of concentration $5 \% \mathrm{KOH}$ at a weight ratio of $1: 12(\mathrm{~g} / \mathrm{ml})$ RHA to solution, respectively, and heated to boiling for $1 \mathrm{hr}$. Then, the mixture was left overnight, filtered and washed twice with distilled water at a weight ratio of 1:8. The filtrate was collected, and subsequently used, as it is predicted to contain leached silica which is the major component of the ash. To the filtrate, $10 \% \mathrm{HCl}$ was added, until the $\mathrm{pH}$ of the solution reached 5-7, to form the silica gel. The obtained silica gel was used in two forms: the first is as it is in the wet form, and the second is after drying in an oven at $120{ }^{\circ} \mathrm{C}$ for sufficient time to the constant weight. 


\subsubsection{The monomer and reagents used:}

The reagents used during copolymerization as monomers (styrene, acrylic acid) and different solvents (Sigma Aldrich), were used without any further purification.

\subsection{Radiation induced grafting:}

The base silica dissolved in sodium hydroxide solution were placed into glass tube and then grafting solution composed of monomer and solvent was added to the tube which were then purged with dry nitrogen for 30 minutes, subsequently sealed and then irradiated at $\mathrm{Co}^{60}$ gamma irradiation cell. Grafting copolymerization reactions were carried out for certain times to achieve reasonable grafting by irradiation dose. The addition of silica and different monomer and solvents were added according to the following table:

Table 1: Preparation of different types of copolymer using different form of silica.

\begin{tabular}{|c|c|c|c|c|c|c|}
\hline $\begin{array}{l}\text { Samples } \\
\text { No. }\end{array}$ & Styrene & AAC & Dioxane & \multicolumn{2}{|r|}{ Silica } & $\begin{array}{c}\text { Swelling } \\
\%\end{array}$ \\
\hline 1 & $3 \mathrm{ml}$ & $6 \mathrm{ml}$ & $3 \mathrm{ml}$ & $2 \mathrm{ml}$ & \multirow[t]{3}{*}{ - Gel form } & 51.15 \\
\hline 2 & $3 \mathrm{ml}$ & $6 \mathrm{ml}$ & $3 \mathrm{ml}$ & $4 \mathrm{ml}$ & & 51.97 \\
\hline 3 & $3 \mathrm{ml}$ & $6 \mathrm{ml}$ & $3 \mathrm{ml}$ & $6 \mathrm{ml}$ & & 51.47 \\
\hline 4 & $3 \mathrm{ml}$ & $6 \mathrm{ml}$ & $3 \mathrm{ml}$ & $2 \mathrm{ml}$ & \multirow{3}{*}{$\begin{array}{l}\text { - Powder form } \\
{[0.2 \mathrm{gm} \text { of silica }+} \\
10 \mathrm{ml} 1 \mathrm{~N} \mathrm{NaOH}]\end{array}$} & 70.86 \\
\hline 5 & $3 \mathrm{ml}$ & $6 \mathrm{ml}$ & $3 \mathrm{ml}$ & $3 \mathrm{ml}$ & & 7626 \\
\hline 6 & $3 \mathrm{ml}$ & $6 \mathrm{ml}$ & $3 \mathrm{ml}$ & $5 \mathrm{ml}$ & & 19.60 \\
\hline 7 & --- & $2.5 \mathrm{ml}$ & $3 \mathrm{ml}$ & $2 \mathrm{ml}$ & \multirow[t]{3}{*}{ - Gel form } & 134.9 \\
\hline 8 & -- & $2.5 \mathrm{ml}$ & $3 \mathrm{ml}$ & $4 \mathrm{ml}$ & & 100.4 \\
\hline 9 & -- & $2.5 \mathrm{ml}$ & $3 \mathrm{ml}$ & $6 \mathrm{ml}$ & & 108.8 \\
\hline 10 & -- & $2.5 \mathrm{ml}$ & $3 \mathrm{ml}$ & $4 \mathrm{ml}$ & \multirow{3}{*}{$\begin{array}{l}\text { - Powder form } \\
{[0.4 \text { gm of silica }+} \\
20 \mathrm{ml} 1 \mathrm{~N} \mathrm{NaOH}]\end{array}$} & 14305 \\
\hline 11 & -- & $2.5 \mathrm{ml}$ & $3 \mathrm{ml}$ & $6 \mathrm{ml}$ & & 24174 \\
\hline 12 & -- & $2.5 \mathrm{ml}$ & $3 \mathrm{ml}$ & $10 \mathrm{ml}$ & & 8254 \\
\hline
\end{tabular}

After dissolving and the addition of silica to the mixture of copolymer sty/AAc and dioxane solvent, the mixture was taken under vigorous steering to the oven at $100{ }^{\circ} \mathrm{C}$ to extract water and then exposed to irradiation dose of $20 \mathrm{KGy}(1.2 \mathrm{~Gy} / \mathrm{second})$. Irradiation of samples was carried out at the National Center for Radiation Research and Technology, NCRRT (AEA), Nasr City, Cairo Egypt. The grafted copolymers were washed with the solvent used during grafting in order to remove residual monomer and/or polymer, which were not bonded to the base copolymer, then dried at $70{ }^{\circ} \mathrm{C}$ and reweighed. 


\subsection{Characterization of prepared copolymer:}

I) Fourier transform infrared spectroscopy (FTIR): The structure of both the base silica and the grafted copolymers was analyzed by Fourier transform infrared (FTIR) spectroscopy. Measurements were carried out in absorbance mode in a wave range of $4000-500 \mathrm{~cm}^{-1}$.

II) Scanning Electron Microscope (SEM): Scanning Electron Microscope-energy dispersive spectroscope, SEM-EDX, (Supra 35VP, Leo, Germany) measurement were conducted to investigate the nitrogen distribution on the surface of the copolymer. An accelerating voltage of $10 \mathrm{kV}$ was used during the measurements.

\section{III) Thermo Gravimetric Analysis (TGA):}

Thermo gravimetric analyses (TGA) of synthesized hydrogels were performed using Polymer Laboratories systems at a heating rate of $20{ }^{\circ} \mathrm{C} / \mathrm{min}$ under nitrogen atmosphere.

\section{VI) Adsorption from solution:}

The different synthetic copolymers grafted to silica, in two different forms (wet gel and dry powder) in different ratio with different volumes of copolymers, were tested for their swelling in water and their feasibility to treatment of different organic compounds and some heavy metals from aqueous solutions.

\section{1) Absorbability of water:}

The tea bag (i.e. a 100 mesh nylon screen) containing an accurately weighed sample (0.1 $\pm 0.001 \mathrm{~g}$ ) was immersed entirely in $200 \mathrm{ml}$ distilled water and allowed to soak for $5 \mathrm{hr}$ at room temperature. The sample particle sizes were $40-60$ meshes $(250-400 \mu \mathrm{m})$. The tea bag was hung up for $15 \mathrm{~min}$ in order to remove the excess water. The swelling \% (S \%) was calculated according to following equation:

$$
\mathrm{S} \%(\mathrm{~g} / \mathrm{g})=\left(\mathrm{W}_{2}-\mathrm{W}_{1}\right) / \mathrm{W}_{1}
$$

Where, $\mathrm{W}_{1}$ and $\mathrm{W}_{2}$ are the weights of dry and swollen gel, respectively.

\section{2) Adsorption of organic compounds and heavy metals from aqueous solutions.}

The prepared new copolymer adsorbents were tested for their efficiency for removal of some organic compounds which are: Methylene Blue (MB), 4-Nitophenol (4-NP), Trartrazine (T) and Congo Red (CR). In addition to organic compounds some of metals such as: $\mathrm{Pb}, \mathrm{Sr}, \mathrm{Ni}$, 
$\mathrm{Co}, \mathrm{Cr}$ and $\mathrm{Fe}$ were used to investigate the efficiency of prepared copolymer for treatment of metal ions from aqueous solutions. A known volume and concentration of each organic and metal ions at its initial $\mathrm{pH}$ was mixed with known weight of each sample of prepared copolymer and shacked at room temperature for $24 \mathrm{hr}$. The residual concentration of each solution was measured using UV and Atomic Absorption spectrophotometer. The uptake of each sample was measured using the following equation:

$$
\text { Uptake }=\left(\mathrm{C}_{\mathrm{o}}-\mathrm{C}_{\mathrm{e}}\right) \mathrm{X}(\mathrm{V} / \mathrm{M})(\mathrm{mg} / \mathrm{g})
$$

Where, $\mathrm{C}_{\mathrm{o}}$ and $\mathrm{C}_{\mathrm{e}}$ are initial and final concentrations of adsorbate. $\mathrm{V}$ is the volume of adsorbate solution (per liter) and $\mathrm{M}$ is copolymer sample weight in gram. And \% removal calculated from the following equation: \% Removal $=\left(C_{0}-C_{e}\right) X\left(100 / C_{o}\right)$.

\section{3- Results and discussion}

\subsection{Adsorption from solution:}

The use of prepared copolymer in the adsorption of some organic compounds and metal ions which used in a different industrial field and scientific application was investigated. In the experimental work it was found that the swilling of the prepared copolymer is the most important property which can affect on their capacity and efficiency in the removal of organic compounds and metal ions during the adsorption processes. Therefore, the swilling of the prepared copolymer in distilled water was studied.

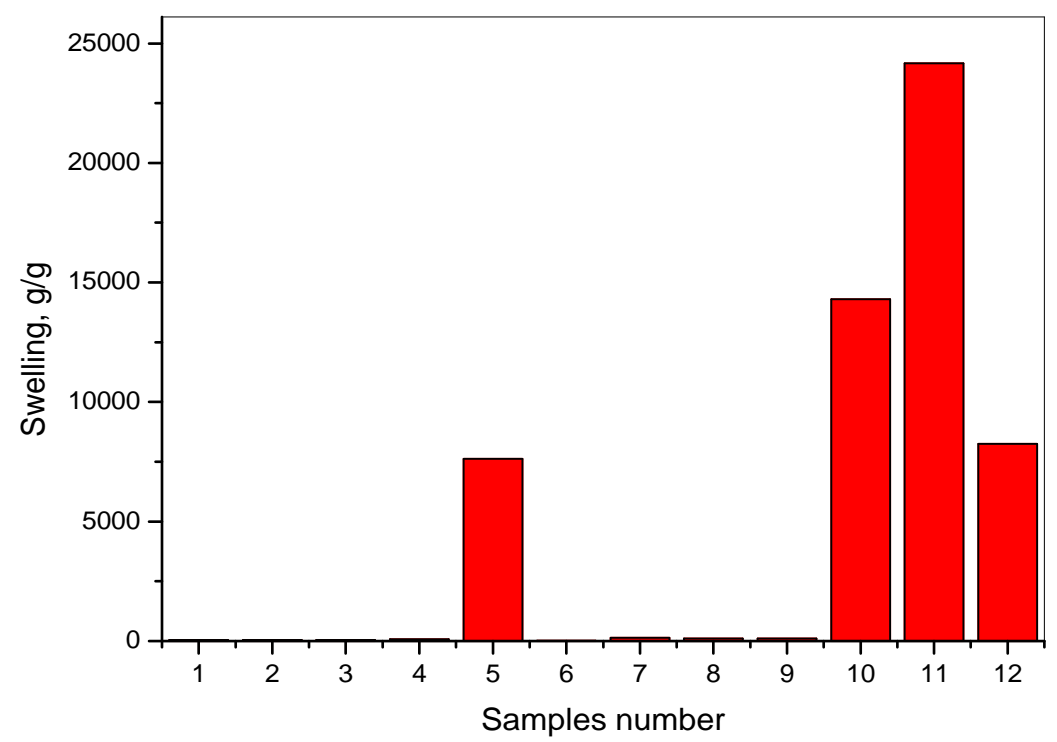

Figure (1): Swelling \% of the prepared copolymer in distilled water. 


\subsubsection{Absorbability of water (swilling \%):}

As seen from the figure and table (1) sample number 11, which was prepared from $2.5 \mathrm{ml}$ AAC, $3 \mathrm{ml}$ Dioxane and $6 \mathrm{ml}$ of solution $(0.4 \mathrm{gm}$ of silica $+20 \mathrm{ml} 1 \mathrm{~N} \mathrm{NaOH})$ based on silica powder form, has the highest swilling \% of all prepared samples. It is also clear that:

- The presence of styrene decrease the swilling $\%$ of the prepared copolymer grafted to silica in both of gel and powder form.

- There is no effect of the increase of the silica volume in the gel form in both cases of the presence and absence of styrene.

- In the powder form, as the silica increases the swilling \% increases to the ratio of (1:2) dioxane to silica solution. But with the increase of silica solution than this ratio, the swilling \% greatly decreases.

- The best result of swilling \% obtained in absence of styrene and presence of AAC and the ratio of $(1: 2)$ dioxane to silica in the powder form.

\subsubsection{Adsorption of organic compounds:}

The following tables $(2 \& 3)$ shows the $\%$ removal and uptake $(\mathrm{mg} / \mathrm{g})$ of Methylene Blue (MB), 4-Nitro Phenol (4-NP), Tartrazine (T) and Congo Red (CR) at different adsorbent dose and $\mathrm{pH}$ values according to the preparation condition of each sample.

\subsubsection{Adsorption Of Methylene Blue Using prepared copolymer.}

Methylene blue (CI 52015) is a heterocyclic aromatic chemical compound with the molecular formula $\mathrm{C}_{16} \mathrm{H}_{18} \mathrm{~N}_{3} \mathrm{SCl}$. It has many uses in a range of different fields, such as biology and chemistry. At room temperature it appears as a solid, odorless, dark green powder that yields a blue solution when dissolved in water. The hydrated form has 3 molecule of water per molecule of methylene blue. ${ }^{[1]}$ As an experimental pharmaceutical drug, the International Nonproprietary Name (INN) of methylene blue is methylthioninium chloride. ${ }^{[2][3]}$. Methylene blue was first prepared in 1876 by German chemist Heinrich Caro (1834-1910). ${ }^{[4]}$ 
<smiles>CN(C)c1ccc2nc3ccc(=[N+](C)C)cc-3sc2c1</smiles>

Methylene blue<smiles>O=[N+]([O-])c1ccc(O)cc1</smiles>

para-nitrophenol

From the following table it is clear that:

1- The presence of styrene in preparation of copolymer from silica in gel form decrease the $\%$ removal (and uptake) of MB. On the contrary, the presence of it in preparation of silica in powder form increases the \% removal (and uptake) of $\mathrm{MB}$ and as the concentration of silica increases the uptake increased.

2- Generally, the obtained results indicated that the highest uptake and \% removal did not depend on the presence or absence of styrene in the preparation of copolymer and the silica is in gel or powder form. And the best result was obtained from sample 6 and 7 as seen from table (2).

3- The absence of styrene in the preparation of copolymer from silica in powder form leads to the increase of swilling $\%$.

4- There is no relationship between the swilling and \% removal (and uptake) of MB.

5- Starting weight of the samples and $\mathrm{pH}$ of the MB after mixing with copolymer had no effect on the \% removal and uptake of MB from solution.

Table (2): Adsorption of MB, 4-NP using prepared copolymer.

\begin{tabular}{|l||l|l|l|l|l||l|l|l|l|}
\hline \hline \multirow{2}{*}{ No } & \multicolumn{5}{|c|}{ MB } & \multicolumn{5}{c|}{ 4-NP } \\
\hline & $\begin{array}{l}\text { Start } \\
\text { weight }\end{array}$ & $\begin{array}{l}\text { Swilling } \\
\%\end{array}$ & $\mathrm{pH}$ & $\% \mathrm{R}$ & $\mathrm{q} \mathrm{e} g / \mathrm{g}$ & $\begin{array}{l}\text { Start } \\
\text { weight }\end{array}$ & $\mathrm{pH}$ & $\% \mathrm{R}$ & $\mathrm{q}$ (mg/g) \\
\hline 1 & 0.0967 & 82.52 & 3.88 & 27.43 & 5.673 & 0.1056 & 3.97 & 1.43 & 1.017 \\
\hline 2 & 0.0997 & 78.13 & 3.72 & 41.58 & 8.341 & 0.0926 & 3.74 & -- & -- \\
\hline 3 & 0.1028 & 51.16 & 3.8 & 24.28 & 4.723 & 0.1139 & 3.6 & 1.1 & 0.724 \\
\hline 4 & 0.1131 & 26.79 & 4.18 & 96.67 & 17.094 & 0.1163 & 4.15 & 21.5 & 13.865 \\
\hline 5 & 0.1047 & 6094.84 & 5.3 & 96.14 & 18.364 & 0.1005 & 5.01 & 12.8 & 9.552 \\
\hline 6 & 0.0972 & 5558.43 & 5.34 & 97.68 & 20.098 & 0.1111 & 5.02 & 6.83 & 4.612 \\
\hline 7 & 0.0960 & 88.54 & 3.6 & 96.3 & 20.062 & 0.0921 & 3.5 & 0.16 & 0.135 \\
\hline 8 & 0.1111 & 69.66 & 3.5 & 96.64 & 17.396 & 0.1072 & 3.46 & 0.9 & 0.629 \\
\hline 9 & 0.1054 & 81.78 & 3.45 & 96.76 & 18.360 & 0.1110 & 3.39 & 4.13 & 2.792 \\
\hline 10 & 0.1108 & 9502.88 & 5.35 & 96.16 & 17.357 & 0.1045 & 5.08 & 11.43 & 8.205 \\
\hline 11 & 0.1047 & 15276.3 & 6.00 & 84.01 & 16.047 & 0.1084 & 5.75 & 82.04 & 56.76 \\
\hline 12 & 0.0971 & 17190.4 & 6.35 & 77.7 & 16.041 & 0.0913 & 6.18 & 100 & 82.146 \\
\hline \hline
\end{tabular}

[For MB: $\mathrm{C}_{0}=100 \mathrm{mg} / \mathrm{l}, \mathrm{V}=20 \mathrm{ml}, \mathrm{pH}_{0}=3.9$, for PNP: $\mathrm{C}_{0}=300 \mathrm{mg} / \mathrm{l}, \mathrm{V}=25 \mathrm{ml}, \mathrm{pH}_{0}=4.71$ ]. 


\subsubsection{Adsorption of 4-nitrophenol:}

4-Nitrophenol (also called p-nitrophenol or 4-hydroxynitrobenzene) is a phenolic compound that has a nitro group at the opposite position of hydroxy group on the benzene ring. 4-Nitrophenol is an intermediate in the synthesis of paracetamol. It is reduced to 4aminophenol, then acetylated with acetic anhydride ${ }^{[1]}$. 4-Nitrophenol is used as the precursor for the preparation of phenetidine and acetophenetidine, indicators, and raw materials for fungicides. In peptide synthesis, carboxylate ester derivatives of 4-nitrophenol may serve as activated components for construction of amide moieties. 4-Nitrophenol irritates the eyes, skin, and respiratory tract. ${ }^{[2]}$ It may also cause inflammation of those parts. It has a delayed interaction with blood and forms methaemoglobin which is responsible for methemoglobinemia, potentially causing cyanosis, confusion, and unconsciousness. ${ }^{[2]}$ When ingested, it causes abdominal pain and vomiting. Prolonged contact with skin may cause allergic response. The $\mathrm{LD}_{50}$ in mice is $282 \mathrm{mg} / \mathrm{kg}$ and in rats is $202 \mathrm{mg} / \mathrm{kg}$. The prepared copolymer was used for adsorption of PNP and the uptake was tabulated as shown in the above table. From the above table:

1- The presence of styrene in preparation of copolymer from silica in gel form decrease the \% removal (and uptake) of 4-NP. But, the presence of it in preparation with silica in powder form increases the \% removal (and uptake) of 4-NP and as the concentration of silica increases the uptake decreased. Whereas in absence of styrene and silica in powder form, as the concentration of silica increases the \% removal of 4-NP reaches $100 \%$.

2- The results indicated that the highest uptake and \% removal was obtained by sample 12 as shown from table (2).

3- There is no relationship between weight of the samples and \% removal (and uptake) of 4-NP.

4- $\mathrm{pH}$ of the 4-NP play an important role in the \% removal where, as the $\mathrm{pH}$ of solution increased the \% removal increased and the highest value of \% removal (100\%) was obtained at $\mathrm{pH}$ of 6.18 .

\subsubsection{Adsorption of tartrazine:}

Tartrazine is a synthetic lemon yellow azo dye primarily used as a food coloring. ${ }^{[1][2]}$ It is also known as E number E102, C.I. 19140, FD\&C Yellow 5, Acid Yellow 23, Food Yellow 4, and Trisodium 1-(4-sulfonatophenyl)-4-(4-sulfonatophenylazo)-5-pyrazolone-3-carboxylate). ${ }^{[3]}$ Tartrazine is a synthetic organic chemical. ${ }^{[4][5]}$ It is water soluble ${ }^{[6]}$ and has a maximum absorbance in an aqueous solution at $427 \pm 2 \mathrm{~nm}^{\left[{ }^{[7]}\right.}$. Tartrazine is a commonly used color all over the world, mainly for yellow, but can also be used with Brilliant Blue FCF (FD\&C Blue 1, E133) or Green S (E142) to produce various green shades. 
<smiles>O=C(O[N+](=O)[O-])c1nn(-c2ccc(S(=O)(=O)O[Na])cc2)c(O)c1/N=N/c1ccc(S(=O)(=O)[O-])cc1</smiles>

Tartrazine

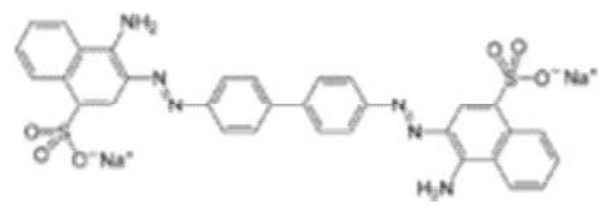

Congo Red

Figure (3): Molecular structure of Tratrazine and Congo Red.

As seen from figure and table (3), the tartrazine has a high molecular size which may decrease the mobility of it through the steps of the adsorption processes leading to the decrease of the adsorption process of such molecules. There is no relationship between sample weight and uptake. The presence of silica in powder form in absence of styrene leads to the prevention of uptake completely. The presence of silica in gel form and in absence of styrene in copolymer makes the uptake of Tartrazine is better than in presence of styrene.

Table (3): Adsorption of tartrazine and Congo red using prepared copolymer.

\begin{tabular}{|c|c|c|c|c|c|c|c|}
\hline \multicolumn{4}{|c|}{ Congo Red } & \multicolumn{3}{|c|}{ Tartrazine } & \multirow[t]{2}{*}{ No } \\
\hline $\mathrm{q}_{\mathrm{e}}(\mathrm{mg} / \mathrm{g})$ & $\% \mathrm{R}$ & $\mathrm{pH}$ & $\begin{array}{c}\text { Starting } \\
\text { weight }\end{array}$ & qe $\mathrm{mg} / \mathrm{g}$ & $\% \mathrm{R}$ & $\begin{array}{l}\text { Starting } \\
\text { weight }\end{array}$ & \\
\hline 74.777 & 52.3 & 5.84 & 0.0525 & 1.765 & 5.26 & 0.1139 & 1 \\
\hline 115.03 & 100 & 5.75 & 0.0652 & 0.983 & 2.93 & 0.0972 & 2 \\
\hline 131.578 & 100 & 4.52 & 0.0570 & -- & -- & 0.1051 & 3 \\
\hline 109.649 & 100 & 4.6 & 0.0684 & 2.644 & 7.88 & 0.0912 & 4 \\
\hline-- & -- & 5.08 & 0.0517 & -- & -- & 0.1010 & 5 \\
\hline 22.441 & 18.88 & 5.17 & 0.0631 & -- & -- & 0.0962 & 6 \\
\hline 104.748 & 100 & 3.78 & 0.0716 & 1.386 & 4.13 & 0.1176 & 7 \\
\hline 102.319 & 100 & 3.74 & 0.0733 & 2.258 & 6.73 & 0.1107 & 8 \\
\hline 101.902 & 100 & 3.76 & 0.0736 & 3.175 & 9.46 & 0.1118 & 9 \\
\hline-- & -- & 5.2 & 0.0639 & -- & -- & 0.0902 & 10 \\
\hline-- & -- & 5.91 & 0.0714 & -- & -- & 0.1108 & 11 \\
\hline- & -- & 6.31 & 0.0631 & -- & -- & 0.1115 & 12 \\
\hline
\end{tabular}

[For tartrazine: $\mathrm{C}_{0}=150 \mathrm{mg} / \mathrm{l}, \mathrm{V}=25 \mathrm{ml}, \mathrm{pH}_{0}=6.18$ and for Congo red:

$$
\left.\mathrm{V}=30 \mathrm{ml}, \mathrm{C}_{0}=250 \mathrm{mg} / \mathrm{l}, \mathrm{pH}_{0}=9.15\right] \text {. }
$$




\subsubsection{Adsorption of congo $\operatorname{red}(\mathrm{CR})$ :}

Congo red is the sodium salt of 3, 3'-([1,1'-biphenyl]-4,4'-diyl) bis (4-aminonaphthalene1-sulfonic acid)(formula: $\mathrm{C}_{32} \mathrm{H}_{22} \mathrm{~N}_{6} \mathrm{Na}_{2} \mathrm{O}_{6} \mathrm{~S}_{2} ;$ molecular weight: $696.66 \mathrm{~g} / \mathrm{mol}$ ). It is a secondary diazo dye. Congo red is water soluble, yielding a red colloidal solution; its solubility is better in organic solvents such as ethanol. Due to a color change from blue to red at $\mathrm{pH} 3.0$ 5.2, Congo red can be used as a $\mathrm{pH}$ indicator.

As seen from the table (3):

- Starting weight of the sample had no effect on the \% removal of CR using prepared copolymer.

- In absence of styrene, preparation of copolymer from silica gel is recommended and leads to $100 \%$ removal of CR whereas preparation from silica powder leads to $0.0 \%$ removal of CR.

- In presence of styrene, preparation of copolymer from silica in gel form is also preferred than silica in powder form and leads to higher \% removal.

- $\mathrm{pH}$ of the solution has no effect on the \% removal of CR using prepared copolymer.

\subsubsection{Adsorption of heavy metals:}

Heavy metals ions such as $\mathrm{Pb}, \mathrm{Sr}, \mathrm{Ni}, \mathrm{Co}, \mathrm{Cr}$ and $\mathrm{Fe}$ (II) in wastewater are hazardous to the environment. These heavy metals are of particular concern to human health. They act as poisonous interference to the enzyme systems and metabolism of the body and tend to accumulate in the food chain and in soft (e.g., kidney) and hard tissues (e.g., bone). Therefore, environmental contamination and exposure to heavy metals ions is a serious growing problem throughout the world [1-3].

Several techniques have been employed for treating wastewater, which include precipitation, chemical reduction, ion-exchange, reverse osmosis, filtration, coagulation and electrolytic recovery. On account of the low operating cost, precipitation and chemical reduction treatment are the most frequently used techniques, especially on the pretreatment of high concentration wastewater. The prepared samples of copolymer were used in this study for removal some of heavy as shown in the following table: 
Table (4): Adsorbability of prepared grafted copolymer toward some heavy metals.

\begin{tabular}{|c|c|c|c|c|c|c|c|c|c|c|c|c|c|c|c|}
\hline TC & 12 & 11 & 10 & 9 & 8 & 7 & $\overline{6}$ & 5 & 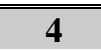 & 3 & 2 & 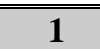 & Samples no. & \multicolumn{2}{|l|}{ Metal } \\
\hline \multirow[t]{3}{*}{524.4} & 24.22 & 60.72 & 88.18 & 50.46 & 46.12 & 52.52 & 73.64 & 90.91 & 22.19 & 7.10 & 5.71 & 2.63 & Uptake (mg/g) & \multirow{2}{*}{$\begin{array}{l}\mathrm{C}_{\mathrm{i}}=200 \\
\mathrm{mg} / \mathrm{l}\end{array}$} & \multirow[t]{3}{*}{$\mathbf{P b}$} \\
\hline & 17657 & 11026 & 8081 & 46.85 & 45.87 & 67.92 & 2367 & 1676 & 43.92 & 76.54 & 82.29 & 82.74 & \% Swilling & & \\
\hline & 5.86 & 5.48 & 4.73 & 3.05 & 3.08 & 3.14 & 4.55 & 4.51 & 3.38 & 3.48 & 3.47 & 3.58 & $\mathbf{p H}_{\mathbf{f}}$ & $\mathrm{pH}_{\mathrm{i}}=5.15$ & \\
\hline \multirow[t]{3}{*}{496.3} & 95.24 & 107.9 & 110.1 & 24.80 & 25.70 & 23.96 & 50.15 & 30.94 & 13.86 & 4.879 & 6.435 & 2.29 & Uptake (mg/g) & \multirow{2}{*}{$\begin{array}{l}\mathrm{C}_{\mathrm{i}}=200 \\
\mathrm{mg} / \mathrm{l}\end{array}$} & \multirow[t]{3}{*}{$\mathrm{Sr}$} \\
\hline & 14969 & 10787 & 3813 & 120.3 & 94.6 & 105.9 & 1186 & 805.6 & $\mathbf{5 7 . 8 4}$ & 54.96 & 66.53 & 53.86 & \% Swilling & & \\
\hline & 5.56 & 4.97 & 4.46 & 3.05 & 3.03 & 3.00 & 4.20 & 4.21 & 3.35 & 3.62 & 3.50 & 3.59 & $\mathbf{p H}_{\mathbf{f}}$ & $\mathrm{pH}_{\mathrm{i}}=5.73$ & \\
\hline \multirow[t]{3}{*}{506.1} & 87.26 & 75.19 & 67.61 & 6.31 & 18.35 & 5.49 & 66.80 & 81.63 & 35.68 & 29.70 & -- & 32.03 & Uptake (mg/g) & \multirow{2}{*}{$\underset{\mathrm{mg} / \mathrm{l}}{\mathrm{C}_{\mathrm{i}}}=200$} & \multirow[t]{3}{*}{$\mathbf{N i}$} \\
\hline & 6348 & 4364 & 1734 & 147 & 118 & 55.89 & 485 & 400 & 78.73 & 130 & 61.52 & 74 & $\%$ Swilling & & \\
\hline & 5.01 & 4.52 & 4.08 & 3.05 & 3.04 & 3.01 & 3.85 & 3.83 & 3.31 & 2.94 & 3.52 & 3.61 & $\mathbf{p H}_{\mathrm{f}}$ & \multirow{3}{*}{$\begin{array}{l}\mathrm{C}_{\mathrm{i}}=200 \\
\mathrm{mg} / \mathrm{l}\end{array}$} & \\
\hline \multirow[t]{3}{*}{237.5} & 47.21 & 62.78 & 44.29 & 2.00 & 3.68 & 5.59 & 27.54 & 34.49 & 7.94 & -- & 1.93 & -- & Uptake (mg/g) & & \multirow[t]{3}{*}{ Co } \\
\hline & 9609 & 4773 & 2133 & 102.8 & 102.7 & 128.12 & 567.8 & 663.02 & 56.18 & 29.84 & 74.03 & 40.31 & \% Swilling & & \\
\hline & 5.27 & 4.88 & 4.34 & 3.38 & 3.36 & 3.37 & 4.23 & 4.22 & 3.71 & 3.93 & 3.64 & 3.95 & $\mathbf{p H}_{\mathbf{f}}$ & $\mathrm{pH}_{\mathrm{i}}=6.46$ & \\
\hline \multirow[t]{3}{*}{8.239} & -- & -- & -- & 1.218 & 0.965 & 1.41 & -- & -- & 0.976 & 1.248 & 1.029 & 1.393 & Uptake (mg/g) & \multirow{2}{*}{$\begin{array}{l}\mathrm{C}_{\mathrm{i}}=200 \\
\mathrm{mg} / \mathrm{l}\end{array}$} & \multirow[t]{3}{*}{$\mathrm{Cr}$} \\
\hline & 14604 & 17519 & 9553 & 103.4 & 83.46 & 107.4 & 4922 & 4317 & 62.02 & 72.75 & 95.44 & 57.01 & \% Swilling & & \\
\hline & 5.88 & 5.6 & 4.94 & 3.26 & 3.2 & 3.22 & 4.73 & 4.7 & 3.75 & 3.64 & 3.51 & 3.65 & $\mathbf{p H}_{\mathbf{f}}$ & $\mathrm{pH}_{\mathrm{i}}=4.5$ & \\
\hline \multirow[t]{4}{*}{273.9} & 90.88 & 78.29 & 56.11 & -- & -- & -- & 29.00 & 19.685 & -- & -- & -- & -- & Uptake (mg/g) & \multirow{2}{*}{$\begin{array}{l}\mathrm{C}_{\mathrm{i}}=200 \\
\mathrm{mg} / \mathrm{l}\end{array}$} & \multirow[t]{3}{*}{$\mathrm{Fe}$} \\
\hline & 231.9 & 125.3 & 70.69 & 91.62 & 79.69 & 86 & 83.51 & 67.49 & 51.01 & 50.61 & 52.12 & 47.12 & $\%$ Swilling & & \\
\hline & 2.38 & 2.11 & 2.04 & 1.98 & 1.97 & 1.97 & 2.02 & 1.96 & 1.97 & 1.92 & 1.96 & 1.99 & $\mathbf{p H}_{\mathrm{f}}$ & $\mathrm{pH}_{\mathrm{i}}=\mathbf{2 . 3 9}$ & \\
\hline & 344.8 & 384.88 & 366.3 & 84.79 & 94.82 & 88.97 & 247.13 & 257.66 & 80.65 & 42.93 & 15.10 & 38.34 & TC & & \\
\hline
\end{tabular}

TC: Total Capacity 


\section{Conclusion}

From this work it can be concluded that:

1- The total capacity of prepared samples toward heavy metal took the following order: $\mathrm{Pb}>\mathrm{Ni}>\mathrm{Sr}>\mathrm{Fe}>\mathrm{Co}>\mathrm{Cr}$.

2- In presence and in absence of styrene, the preparation of copolymer from silica in powder form is preferred than in gel form where it leads to higher adsorption and removal capacity of the studied metals ions.

3- Sample number 11 had the highest adsorption and \% removal capacity for studied metal ions and sample number 2 had the lowest values.

\section{References}

1. Gürsel, S. A.; Gubler, L.; Gupta, B.; Scherer, G. G. Advances in Polymer Science. Fuel Cells I; 215; Springer: Berlin, 2008.

2. Gubler, L.; Gürsel, S. A.; Scherer, G. G. Fuel Cells 2005, 5, 317.

3. Gubler, L.; Prost, N.; Gürsel, S. A.; Scherer, G. G. Solid State Ionics 2005, 176, 2849.

4. Gürsel, S. A.; Yang, Z.; Choudhury, B.; Roelofs, M. G.; Scherer, G. G. J Electrochem Soc 2006, 53, A1964.

5. Gubler, L.; Ben youcef, H.; Gürsel, S. A.; H.; Wokaun, A.; Scherer, G. G. J Electrochem Soc 2008, 155, B921.

6. Schmidt, C.; Schmidt-Naake, G. Macromol Mater Eng 2007, 292, 1164.

7. Brack, H. P.; Bührer, H. G.; Bonorand, L.; Scherer, G. G. J Mater Chem 2000, 10, 1795.

8. Chapiro, A.; Radiation Chemistry of Polymeric Systems; Wiley-Interscience: New York, 1962.

9. Rabie, A. M.; Aly, M. I.; Hegazy, E. S. A.; El-Awady, N. I. Polymer J 1979, 11, 359.

10. Hegazy, E. S. A.; Dessouki, A. M.; El-Dessouky, M. M.; El-Sawy, N. M. Radiat Phys Chem 1985, 26, 143.

11. Yang, J .; Hsiue, G. H. J Appl Polym Sci 1990, 39, 1475.

12. Rath, S. K.; Palai, A.; Rao, S.; Chandrasekhar, L.; Patri, M. J Appl Polym Sci 2008, 108, 4065.

13. Hegazy, E. S. A. J Polym Sci Polym Chem Ed 1984, 22, 493. 23 
14. Hegazy, E. A.; Mokhtar, S. M; Osman M. B. S.; Mostafa, A.E.B. Radiat Phys Chem 1990, 36,365 .

15. Hegazy, E. S. A.; Osman M. B. S.; Mokhtar, S. M.; Mostafa, A. E. B. Polymer 1992, 33, 4230.

16. Dessouki, A. M.; Taher, N. H.; El-Arnaouty, M. B. Polym Int 1999, 48, 92.

17. Al Sagheer, F. A.; El-Sawy, N. M. J Appl Polym Sci 2000, 76, 282.

18. Kaur, I.; Kumar, S.; Misra, B. N., Chauhan, G. S. Mater Sci Eng 1999, A 270, 137.

19. Kaur, I.; Kumar, S.; Chauhan, G. S.; Misra, B. N. J Appl Polym Sci 1999, 73, 2959.

20. Walsby, N.; Paronen, M.; Juhanoja, J.; Sundholm, F. J Polym Sci Part A Polym Chem 2000, 38, 1512.

21. Nasef, M. M. Polym Int 2001, 50, 338.

22. Kang, K.; Kang, P. H.; Nho, Y. C. J Appl Polym Sci 2006, 99, 1415.

23. Kimura, Y.; Asano M.; Chen, J.; Maekawa, Y.; Katakai, R.; Yoshida, M. Radiat Phys Chem 2008, 77, 864.

24. Bozzi, A.; Chapiro, A.; Radiat Phys Chem 1988, 32,193.

25. Brandrup, J.; Immergut, E. H. (eds). Polymer Handbook; Wiley Interscience Publications: New York, 1989.

26. Howard, G. L.; Lai, S. H.; J Polym Sci Polym Chem Ed 1979, 17, 378

27. Gürsel, S. A.; Ben youcef, H.; Wokaun, A.; Scherer, G. G. Nucl Instr and Meth in Phys Res B 2007, 265, 198

28. Rudin A, The Elements of Polymer Science and Engineering; Academic Press: New York, 1982.

29. Arichi, Shizuo.; Matsurra, H.; Tanimoto, Y.; Murata, H. Bull Chem Soc Jpn 1966, 39, 434.

30. Nasef, M. M.; Saidi, H.; Dahlan, K. M. Z. Radiat Phys Chem 2003, 68, 875.

31. Socrates, G. Infrared Characteristics Group Frequencies, Tables and Charts; John Wiley \& Sons: Chichester, 1994.

32. Starkweather, H. W. J Polym Sci Polym Phys Ed 1973, 11, 587.

33. Feng, J.; Chan, C. M. Polymer 1997, 38, 6371.

34. Saarinen, V.; Karesoja, M.; Kallio, T.; Paronen, M.; Kontturi, K. J Memb Sci 2006, 280, 20.

35. http://www.methylene-blue.com/substance.php 
36. Adams V., Marley J., McCarroll C. (November 2007). "Prilocaine induced methaemoglobinaemia in a medically compromised patient. Was this an inevitable consequence of the dose administered?". Br. Dent. J. 203 (10): 585-7. doi: $10.1038 / \mathrm{bdj} .2007 .1045$. PMID 18037845.

37. Linz A.J., Greenham R.K., Fallon L.F. (May 2006). "Methemoglobinemia: an industrial outbreak among rubber molding workers". J. Occup. Environ. Med. 48 (5): 523-8. doi: 10.1097/01.jom.0000201815.32098.99. PMID 16688009.

38. Badische Anilin- und Sodafabrik [BASF] (Mannheim, Germany), "Verfahren zur Darstellung blauer Farbstoffe aus Dimethylanilin und anderen tertiaren aromatischen Monaminen" (Method for preparation of blue dyes from dimethylaniline and other tertiary aromatic monoamines), Deutsches Reich Patent no. 1886 (December 15, 1877). Available on-line at: P. Friedlaender, Fortschritte der Theerfarbenfabrikation und verwandter Industriezweige (Progress of the manufacture of coal-tar dyes and related branches of industry), volume 1 (Berlin, Germany: Julius Springer, 1888), pages 247-249. See also:

39. British patent no. 3751 (October 9, 1877).

40. Heinrich Caro, "Improvement in the production of dye-stuffs from methyl-aniline," U.S. Patent no. 204,796 (filed: March 28, 1878 ; issued: June 11, 1878).

41. Ellis, Frank (2002). Paracetamol: a curriculum resource. Cambridge: Royal Society of Chemistry. ISBN 0-85404-375-6.

42. Toxicological Profile For Nitrophenols. Agency for Toxic Substances and Disease Registry, U.S. Public Health Service. July 1992

43. A. Figoli, A. Cassano, A. Criscuoli, M.S.I. Mozumder, M.T. Uddin, M.A. Islam, E. Drioli, Influence of operating parameters on the arsenic removal by nanofiltration, Water Research (2010) 97-104.

44. T. Nishitani, I. Fukunaga, H. Itoh, et. al, The relationship between $\mathrm{HCl}$ and mercury speciation in flue gas from municipal solid waste incinerators, Chemosphere 39 (1999) 19.

45. U.S. EPA, Industrial Waste Study: Mercury Using Industries, EPA/805/25-18/000 HIP 07/71, 1971. 